\title{
РОЛЬ І ФУНКЦІЯ ЛІКАРЕНЬ (АНАЛІТИЧНИЙЙ ОГЛЯД ЛІТЕРАТУРИ)
}

\author{
${ }^{1}$ ДУ “Український інститут стратегічних досліджень МОЗ України”, м. Київ \\ ${ }^{2}$ Ужгородський національний університет, Україна
}

\begin{abstract}
Мета: проаналізувати джерела наукової літератури щодо ролі та функцій лікарень.
Матеріали і методи. У дослідженні застосовано бібліосемантичний метод - проаналізовано 58 джерел наукової літератури.

Результати. Центральною функцією лікарень є лікування хворих, однак роль лікарні не можна обмежувати тільки цією функцією, лікарня також може бути важливим місцем для навчання та проведення наукових досліджень, підтримувати розташовані поруч заклади охорони здоров'я. Лікарня, що надає багато робочих місць, грає важливу соціальну роль.

Висновки. Очікування, пов'язані з кожною із функцій, значно впливають на організацію діяльності лікарні та на структуру їі зв'язків. Отримані в ході дослідження результати мають бути використані при розробці стратегії подальшого проведення реформи системи охорони здоров'я в Україні та формування мережі лікарень на всіх рівнях управління.
\end{abstract}

КЛЮЧОВІ СЛОВА: лікарня, роль, функції, світовий досвід.

На даному етапі функціонування системи охорони здоров'я в Україні управлінські та фінансові зусилля зосереджені не на задоволенні медичних потреб населення, а на вирішенні потреб закладів охорони здоров'я (ЗОЗ) та системи в цілому, що призводить до деформованості структури медичних послуг, порушення принципів справедливості та низької якості медичної допомоги; незаінтересованості медичних працівників у підвищенні ефективності праці [8;9;12].

Мета роботи: провести аналіз джерел наукової літератури щодо ролі та функцій лікарень.

Матеріали і методи. У дослідженні застосовано бібліосемантичний метод - проаналізовано 58 джерел наукової літератури.

Результати дослідження та їх обговорення. У ході проведеного дослідження встановлено, що центральною функцією лікарень є лікування хворих [15]. При цьому роль лікарні не можна обмежувати тільки цією функцією, лікарня також може бути важливим місцем для навчання та проведення наукових досліджень. Вона може також активно підтримувати розташовані поруч 303. Крім того, лікарня, що надає багато робочих місць, грає важливу соціальну роль. Очікування, пов'язані з кожною із названих функцій, значно впливають на організацію діяльності лікарні та на структуру зв'язків з їі оточенням [21].

Слід зазначити, що між лікарнями існують значні типологічні відмінності. Типи лікарень можна класифікувати у ієрархічному порядку: лікарні

(ㄷ Г.Я. Пархоменко, В.Г. Слабкий, 2014 третього рівня (часто національного чи регіонального рівня, вони зазвичай пов'язані з університетами), лікарні другого рівня (окружні) і комунальні та сільські лікарні. Відмічають також спеціалізовані лікарні та лікарні загального профілю [58]. Водночас слід зазначити, що в країнах з високим рівнем життя межі між лікарнями другого та третього рівнів повільно стираються [19].

Крім того, в умовах зростаючої спеціалізації неможливо точно визначити, яку кількість жителів має обслуговувати лікарня, що належить до третього рівня. Кожна лікарняна спеціальність має свою норму охоплення населення. Так, у підрозділах нейрохірургічного профілю вона вища, ніж онкологічного профілю. Серед лікарень третього рівня також розвивається своя спеціалізація. Так, на десять лікарень третього рівня з кардіохірургічними ліжками для дорослого населення може припадати тільки одна 3 відповідними ліжками для дитячого населення [10].

Також втрачається традиційний розподіл між університетськими клініками та іншими лікарнями. Можливості навчання медичних працівників розширюються. Модель, згідно з якою навчання було сконцентровано головним чином в обладнаних найновішим обладнанням лікарнях третього рівня, де лікуються пацієнти з найбільш важкими та складними випадками захворювань, не підходить для навчання студентів, які готують себе до роботи сімейним лікарем. Така модель не має особливого відношення до повсякденної клінічної практики [53]. 
У сучасних умовах з'являються нові характеристики лікарень, серед яких - структурна організація (право власності, вид фінансування), функції (типи лікування хворих), мета (забезпечення доступу до медичних послуг чи забезпечення прибутків), способи оцінки результатив- ності (задоволення пацієнтів, низький рівень післяопераційних ускладнень тощо) [22].

У табл. 1 наведено перелік аспектів лікарень та показано, як можна вимірювати змінні показники. Дані таблиці підтверджують гіпотезу про те, що лікарня - це складна організаційна структура, яка не піддається однозначній класифікації [20].

Таблиця 1. Опис лікарні: аспекти і показники

\begin{tabular}{|c|c|}
\hline Аспект & Показник \\
\hline \multicolumn{2}{|r|}{ Місие знаходження } \\
\hline Географічний рівень & Національна, регіональна, окружна або комунальна \\
\hline Структура міста & Унітарна або складова \\
\hline \multicolumn{2}{|r|}{ Керівництво } \\
\hline Власник & $\begin{array}{l}\text { Федеральна, регіональна або місцева виконавча влада; міністерство } \\
\text { охорони здоров'я чи інше міністерство; автономний державний } \\
\text { сектор; некомерційний благочинний сектор; акціонерна компанія; } \\
\text { комерційна організація }\end{array}$ \\
\hline Керівник адміністрації & $\begin{array}{l}\text { Професійні управлінці, технократи, професіонали-лікарі або } \\
\text { непрофесіонали }\end{array}$ \\
\hline \multicolumn{2}{|r|}{ Фінанси } \\
\hline Основне джерело фінансування & Держава, медичні фонди, збори з хворих тощо \\
\hline Структура витрат & $\begin{array}{l}\text { Високі витрати або низькі витрати (на кожного хворого, категорію } \\
\text { хворих, бюджетний рік або ліжко), середня зарплата для всього } \\
\text { персоналу або для певної категорії персоналу }\end{array}$ \\
\hline Методи оплати & $\begin{array}{l}\text { Постатейний бюджет, глобальний бюджет або бюджет, зумовлений } \\
\text { діяльністю }\end{array}$ \\
\hline \multicolumn{2}{|r|}{ Розмір } \\
\hline Охоплення населення & $\begin{array}{l}\text { Географічний або інший принцип охоплення населення (наприклад, } \\
\text { охоплення військових) }\end{array}$ \\
\hline Чисельність персоналу & $\begin{array}{l}\text { Загальна чисельність, чисельність на одне ліжко, на } 100 \text { хворих або } \\
\text { на одного лікаря; доля середнього медичного персоналу }\end{array}$ \\
\hline Розмір лікарні & Число ліжок (стаціонарних чи амбулаторних) \\
\hline \multicolumn{2}{|r|}{ Ступінь складності } \\
\hline \begin{tabular}{lll|} 
Відношення лікарні до навчального \\
процесу
\end{tabular} & Лікарня при вищому навчальному закладі або не $\epsilon$ навчальною базою \\
\hline Тип лікарні & $\begin{array}{l}\text { Другого чи третього рівня; загального профілю або спеціалізована; } \\
\text { для лікування гострих випадків, для видужуючих, для паліативного } \\
\text { догляду або змішаного типу }\end{array}$ \\
\hline Спеціалізація & Одна чи декілька; число та типи спеціалізацій \\
\hline Технологія & Тип технології та ступінь технічної оснащеності \\
\hline \multicolumn{2}{|r|}{ Особливості діяльності } \\
\hline Акредитація & Наявність або відсутність акредитації \\
\hline Результативність & Оцінка роботи за шкалою показників діяльності \\
\hline Контроль над пацієнтами & Первинний медсестринський догляд, робота багатопрофільної групи \\
\hline Ступінь задоволеності хворих & Опитування пацієнтів, кількість скарг \\
\hline Чутливість & Терміни очікування черги \\
\hline Ступінь задоволеності персоналу & Показники прийому на роботу та плинність кадрів \\
\hline Активність & Висока або низька \\
\hline Чисельність хворих & $\begin{array}{l}\text { Стаціонарні хворі; випадки, що не потребують перебування на термін } \\
\text { більше доби; епізоди; склад випадків госпіталізації }\end{array}$ \\
\hline Коефіцієнт використання ліжок & Середнє число зайнятих ліжок на рік \\
\hline Кількість прийнятих хворих & На 100 чоловік населення \\
\hline Середні терміни перебування & Число днів \\
\hline Результати & $\begin{array}{l}\text { Летальність протягом } 30 \text { днів після госпіталізації; відсоток } \\
\text { лікарняних інфекцій; відсоток «лікарських помилок»; термінова } \\
\text { госпіталізація менше, ніж через } 28 \text { днів після виписки }\end{array}$ \\
\hline
\end{tabular}


Останнім часом предметом уваги стають лікарні третього рівня. Лікарні третього рівня надають найскладніші види медичних послуг, вони, як правило, оснащені найсучаснішою медичною технікою, пов'язані з навчальними закладами і представляють регіональний рівень. Лікарні третього рівня можуть бути як загального профілю (об'єднувати певну кількість спеціальностей), так і спеціалізовані (обслуговувати ту чи іншу групу населення, спеціалізуватися на тих чи інших захворюваннях чи методах лікування) [34;39]. Багато авторів виключність вказаних функцій лікарень третинного рівня ставлять під сумнів [50].

У другій половині XIX століття відмічається зростання числа спеціалізованих лікарень, що пов'язано зі спеціалізацією серед медичних працівників [47]. Лікарні цього типу залучали медичну еліту і тому набули достатньо високого професійного і соціального статусу [41]. Це ортопедичні, офтальмологічні, онкологічні, наркологічні, дитячі лікарні. Але у більшості країн Європи ця модель поступово поступається моделі лікарні загального профілю [48;54;56]. Злиття спеціалізованих 303 з лікарнями загального типу, починаючи з кінця XX століття, відбувається і в Україні [7].

Далі коротко зупинимося на характеристиці окремих функцій лікарні.

Лікування хворих - визначальна функція лікарні, яка спрямована на лікування гострих випадків. Найважливіші аспекти цієї функції зводяться до наступного: термінове чи планове лікування, стаціонарне чи амбулаторне лікування, лікування гострих випадків чи реабілітація. Однак типологія пацієнтів, яким надається медична допомога лікарнями, має значну різницю і залежить від організаційних підходів в тій чи іншій національній системі охорони здоров'я [17].

Стаціонарне лікування є найбільш важливою функцією лікарень [13]. Незважаючи на те, що загальне число лікарень та ліжок у Західній Європі знизилося, прийом хворих невпинно зростає завдяки тому, що більшість пацієнтів госпіталізуються на відносно короткий курс інтенсивного лікування [16]. У деяких країнах Європи середні терміни перебування хворих на госпітальному ліжку складають до 6 днів [57]. В Україні, незважаючи на один із найвищих рівнів забезпеченості населення лікарнями та лікарняними ліжками, залишаються і одними з найбільших середні терміни перебування пацієнтів на стаціонарному лікуванні [2].

У країнах Західної Європи скорочення термінів перебування пацієнтів при старінні населення та надходженні до лікарень пацієнтів у тяжкому стані пов'язано із використанням нових технологій, сучасного діагностичного та лікувального обладнання та засобів медичного призначення. Наприклад, використання уже з 1980-х років у хворих 3 інфарктом міокарда тромболізису та термінової ангіопластики [49]. Зміна структури лікування та запровадження сучасного обладнання вимагає нових підходів у кадровій політиці: необхідні спеціалісти, які мають медичну освіту з високою технічною кваліфікацією та кваліфіковані керівники, які здатні керувати складною структурою лікувального закладу. Крім того, необхідно враховувати і потреби пацієнтів - вони вимагають комфортних та безпечних умов перебування в лікарні [37].

Другий аспект характеристики лікарні полягає в диференціації між плановим і терміновим лікуванням. Лікування невідкладних станів є найважливішою функцією лікарень. Термінове лікування в лікарні рятує життя, однак тільки в тих випадках, коли стан хворих стабілізовано, коли вони швидко доправлені до лікарні, коли медична допомога, що їм надається, відповідає тяжкості стану пацієнта [36].

Дискусії про створення служби невідкладної допомоги започатковані під впливом наступного відкриття: в США серед померлих від травм біля 50\% помирають відразу, оскільки травми є несумісними із життям, 30\% помирають між першою та четвертою годинами від попереджувальних причин, 20\% помирають від пізніх ускладнень [55].

Один із підходів полягає у спеціальній підготовці середнього медичного персоналу для невідкладної допомоги при ситуаціях, які загрожують життю. На противагу цьому були надані пояснення, що процес реанімації на місці травми затримує перевезення потерпілого до лікарні, а покращання тканинного кровообігу підвищує ризик кровотечі під час перевезення [52].

Інший підхід полягав у тому, що на місце пригоди має прибути лікар [42], а перевезення травмованого вертольотом може підвищити шанс на виживання [51].

Створення спеціалізованих травматологічних центрів призвело до зниження смертності від нещасних випадків у США [46]. Вказані центри характеризує наступне: по-перше, старший медичний персонал, який представляє певні спеціальності, має знаходитися в центрі постійно; подруге, центри тісно взаємодіють із службами швидкої допомоги; по-третє, через кожний центр щотижня проходить 10-20 тяжко травмованих хворих [40].

Однак у Великій Британії створення подібних центрів за американською моделлю не мало очікуваної ефективності [44]. Отже організаційну методологію втручань необхідно розробляти з урахуванням національного контексту. У деяких 
країнах, насамперед пострадянського простору, були створені лікарні невідкладної допомоги [28]. Існування таких центрів є перепоною для розвитку сучасних лікарень загального профілю, які надають інтегрований пакет медичних послуг.

При цьому слід зазначити, що відділення невідкладної допомоги певною мірою виконують функцію первинної допомоги, що небажано [45]. 3 іншого боку, пацієнти допускають, що подібне поєднання первинної і невідкладної допомоги є доцільним [26]. Один із методів «фільтрації» менш складних випадків полягає у створені автономних закладів для лікування незначних ушкоджень [29]. Другий метод - робота у відділеннях невідкладної допомоги лікарів первинної ланки, які здатні надавати більш ефективну та економічну медичну допомогу [36].

В Україні питанням організації інтенсивної медичної допомоги останнім часом присвячена велика кількість наукових робіт [1;3]. Вивчалися питання мережі, структури, ресурсного забезпечення, якості та результативності термінової медичної допомоги, як на догоспітальному, так і госпітальному етапах [4;5;6]. Була обґрунтована необхідність створення різнопрофільних спеціалізованих центрів та показана їх ефективність, а в умовах реформування системи медичної допомоги населення формування госпітальних округів [14] з формуванням лікарень інтенсивного лікування [11].

У поняття “амбулаторне лікування" входить цілий ряд різноманітних видів діяльності, які включають послуги відповідних клінік, різні складні форми лікування (діаліз, хіміотерапія тощо) та проведення в амбулаторних умовах хірургічних операцій. Але до останнього часу роль амбула- торного лікування у різних системах охорони здоров'я практично не досліджувалась [25].

В Україні амбулаторне лікування пацієнтів здійснюється через мережу домашніх та денних стаціонарів [18].

Розглянемо ще один елемент лікування хворих - реабілітацію. Кращі результати приносять програми активної реабілітації, які пропонують допомогу через багатопрофільні групи лікарів [30]. Взірцем може слугувати діяльність багатопрофільних груп реабілітації після інсульту [31]. Денні лікарні дозволяють пацієнтам вечорами повертатися додому, що не обов'язково призводить до кращих результатів, ніж реабілітація в стаціонарі, особливо у людей похилого віку [35]. Друга альтернатива - реабілітація в домашніх умовах, але важко сказати, наскільки вона ефективніша, ніж реабілітація в денних центрах чи стаціонарах [32]. Проблема організаційних форм реабілітації активно обговорюється і в Україні.

Важливою функцією лікарень є також навчання та проведення досліджень, які тісно пов'язані з лікування пацієнтів [38]. Дані функції лікарень повинні враховуватися під час проектування лікарень [23]. Але існує небезпека, що прагнення до підвищення економічності лікарень призведе до зниження питомої ваги даної функції. Але можливо, що фінансова вигода від подібних заходів зрештою буде несуттєвою [26;33;43].

Слід зазначити, що лікарні - це не тільки місце, де професіональні медичні працівники ставлять діагнози та лікують хворих. Лікарні відіграють певну громадську роль і в зв'язку з цим наділені певною сукупністю різних значень (табл. 2). Для успіху реформи необхідно, щоб відповідальні за розробку політики особи, змогли гідно оцінити цей аспект.

Таблиця 2. Альтернативні значення лікарень

\begin{tabular}{|l|l|l|}
\hline \multicolumn{1}{|c|}{ Аспект } & \multicolumn{2}{|c|}{ Альтернативні значення } \\
\hline Легітимізація держави & Пріоритетна політична проблема & $\begin{array}{l}\text { Непріоритетна політична } \\
\text { проблема }\end{array}$ \\
\hline Політичний індикатор & Загальне благо & Приватна зручність \\
\hline Громадянський здобуток & Лікарня в кожному місті & Регіональні заклади \\
\hline $\begin{array}{l}\text { Показник стану системи охорони } \\
\text { здоров’я }\end{array}$ & Домінуюча лікарня & Частина системи охорони здоров’я \\
\hline $\begin{array}{l}\text { Постачальник медичної допомоги } \\
\text { Кращі медичні сили }\end{array}$ & $\begin{array}{l}\text { Осдична і соціальна допомога } \\
\text { професійних сил }\end{array}$ & $\begin{array}{l}\text { Невідкладна допомога } \\
\text { тяжкохворим }\end{array}$ \\
\hline
\end{tabular}

\section{Висновки}

Таким чином, діяльність лікарні має багато аспектів. Отримані в ході дослідження результати мають бути використані в ході розробки стратегії подальшого проведення реформи системи охорони здоров'я в Україні та формування мережі лікарень на всіх рівнях управління.

Перспективи подальших досліджень пов'язані з вивченням ефективності діяльності лікарень різного типу, які створюються в ході реформи системи медичної допомоги в Україні. 


\section{Список літератури}

1. Вплив основних складових лікувально-діагностичного процесу на летальність у відділеннях анестезіології та інтенсивної терапії / В. М. Князевич, Г. О. Слабкий, Р. М. Федосюк, О. М. Ковальова // Здоровье женщины. 2009. - № 6 (42). - С. 22-33.

2. Здоров'я населення та діяльність охорони здоров'я України : європейський вимір (за даними вибіркових індикаторів бази даних Європейського Регіонального Бюро Всесвітньої Організації Охорони Здоров'я) / Ф. Ф. Ринда, Є. М. Кривенко, Р. Й. Лихотоп [та ін.]; за ред. З. М. Митника. - К. : МОЗ; УІСД, 2010. - 89 с.

3. Кадрове забезпечення служби анестезіології та інтенсивної терапії лікувальних закладів України II-ІІІ рівнів надання медичної допомоги / В. М. Князевич, Г. О. Слабкий, Р. М. Федосюк, О.М.Ковальова // Проблеми екології та медицини. - 2009. - Т. 13, № 1-2. - С. 3-12.

4. Кадрове забезпечення служби анестезіології та інтенсивної терапії лікувальних установ України II-III рівні надання медичної допомоги / В. М. Князевич, Г. О. Слабкий, Р. М. Федосюк, О. М. Ковальова // Лікар. справа / Врачеб. дело. - 2009. - № 7-8. - С. 98-106.

5. Князевич В. М. Характеристика забезпечення відділень інтенсивної терапії лікувальних закладів України моніторинговою апаратурою / В. М. Князевич // Совр. педиатрия. - 2009. - № 1 (23). - С. 10-13.

6. Князевич В. М. Характеристика структури та організації діяльності служби анестезіології та інтенсивної терапії системи охорони здоров'я України / В. М. Князевич // Біль, знеболювання і інтенсивна терапія. - 2009. - № 1. - C. 2-8.

7. Лехан В. М. Проблеми та перспективи перебудови стаціонарної медичної допомоги вторинного рівня / В. М. Лехан, Л. В. Крячкова, В. В. Волчек // Східноєвроп. журн. громад. здоров'я. - 2008. - Т. 2, № 2. - С. 4452.

8. Лехан В. М. Стратегія розвитку системи охорони здоров'я: український вимір / В. М. Лехан, Г. О. Слабкий, М. В. Шевченко. - К., 2009. - 50 с.

9. Медико-демографічна ситуація та організація медичної допомоги населенню : підсумки діяльності системи охорони здоров'я України за 2008 рік : монографія / за ред. В. М. Князевича; МОЗ України, УІСД МОЗ України. - К., 2009. - 122 с.

10. Основні показники діяльності обласних лікарень України. 2008 рік. (Аналіз інтегральних показників та рейтингова оцінка) / М. П. Жданова, О. М. Коллякова, Н. Ю. Кондратюк [та ін.]; за ред. Міністра охорони здоров'я України В. М. Князевича. - К., 2009. - 46 с.

11. Основні шляхи подальшого розвитку системи охорони здоров'я в Україні. Спільний звіт / за заг. ред. В. М. Лехан, В. М. Рудого. - К. : Вид-во Раєвського, 2005. - 168 с.

12. Охорона здоров'я України: стан, проблеми, перспективи : спеціалізоване видання] / В. М. Князевич, В. В. Лазоришинець, І. В. Яковенко [та ін.]. - Київ-Тернопіль, 2009. - 440 с.

13. Охорона здоров'я України: проблеми та напрямки розвитку / В. М. Лехан, Г. О. Слабкий, М. В. Шевченко [та ін.] // Вісн. соц. гігієни та орг. охорони здоров'я України. - 2011. - № 4.

14. Позитивний досвід реформування галузі охорони здоров'я регіонів / О. В. Аніщенко, Р. О. Моісеєнко, О. К. Толстанов [та ін.]. - К., 2011. - 149 с.

15. Салтман Р. Б. Реформы системы здравоохранения в Европе. Анализ современных стратегий : пер. с англ. / Р. Б. Салтман, Дж. Фигейрас. - М. : Геотар Медицина, 2000. - 432 с.

16. Системы здравоохранения, здоровье и благосостояние: оценка аргументов в пользу инвестирования в системы Здравоохранения / Josep Figueras, Martin Mc Kee, Suszy Lessof [et al.]. - BO3, 2008.

17. Системы здравоохранения: улучшение деятельности. Доклад о состоянии здравоохранения в мире 2000 г. Женева : ВОЗ, 2000. - 232 с.

18. Ситуаційний аналіз розвитку сімейної медицини в Україні. 2010 р. / О. І. Антонишин, П. С. Бондарчук, М. В. Денисенко [та ін.] ; за ред. Г. О. Слабкого. - К. : МОЗ, ДУ «УІСД МОЗ України», 2011. - 28 с.

19. Скляр С. І. Реформування системи охорони здоров'я: світовий досвід та Україна (огляд літератури) / С. І. Скляр, Н. Ю. Кондратюк // Україна. Здоров'я нації. - 2008. - № 2 (6). - С. 82-87.

20. Слабкий Г. А. Вопросы оценки деятельности стационаров в интерпретации ВОЗ / Г. А. Слабкий, Г. Я. Пархоменко // Україна. Здоров'я нації. - 2011. - № 2 (18). - С. 7-15.

21. Слабкий Г. О. Модель лікарні майбутнього / Г. О. Слабкий, Г. Я. Пархоменко. - К., 2010. - 60 с.

22. Тульчинский T. Х. Новое общественное здравоохранение: введение в современную науку / Т. Х. Тульчинский, Е. А. Варавикова. - Иерусалим : Amutah for Education and Health, 1999. - 1049 c.

23. A case of market failure // Lancet. - 2000. - Vol. 355. - P. 1657.

24. American College of Surgeons Committee on Trauma Resources for Optimal Care of the Injured Patient. - Chicago, IL : American College of Surgeons, 1990

25. Berman P. Organization of ambulatory care provision: a critical determinant of health system performance in developing countries, Bulletin of the World Health Organization / P. Berman // The International Journal of Public Health. - 2000. -Vol. 78 (6). - P. 791-802.

26. Bevan G. The medical service increment for teaching (SIFT): a 400m anachronism for the English NHS? / G. Bevan / / British Medical Journal. - 1999. - Vol. 319. - P. 908-11.

27. Calnan M. The functions of the hospital emergency department: a study of patient demand / M. Calnan // Journal of Emergency Medicine. - 1984. - Vol. 2. - P. 57-63. 
28. Cost effectiveness of treating primary care patients in accident and emergency: a comparison between general practitioners, senior house officers and registrars / Dale J., Lang H., Roberts J. A. [et al.] // British Medical Journal. - 1996. - Vol. 312 (7042). - P. 1340-4.

29. Dale J. Do patients use minor injury units appropriately? / J. Dale, B. Dolan // Journal of Public Health Medicine. 1996. - Vol. 18. - P. 152-6.

30. Dickinson E. Effective Practice in Rehabilitation - Reviewing the Evidence / E. Dickinson, A. Sinclair. - London : King's Fund, 1998.

31. Do stroke units save lives? / Langhorne P., Williams B. O., Gilchrist W., Howie K. // Lancet. - 1993. - Vol. 342. P. 395-8.

32. Does hospital at home make economic sense? Results of an economic evaluation of early discharge hospital at home care for orthopaedic patients in three areas of West London / Hensher M., Fulop N., Hood S., Ujah S. // Journal of the Royal Society of Medicine. - 1996. - Vol. 89. - P. 595-600.

33. Field M. G. Noble purpose, grand design, flawed execution, mixed results: Soviet socialized medicine after seventy years / M. G. Field // American Journal of Public Health. - 1990. - Vol. 80. - P. 144-5.

34. Florin D. Evaluating NHS direct: early findings raise questions about expanding the service / D. Florin, R. Rosen // British Medical Journal. - 1999. - Vol. 319. - P. 5-6.

35. Forster A. Systematic review of day hospital care for elderly people: the Day Hospital Group / A. Forster, J. Young, P. Langhorne // British Medical Journal. - 1999. - Vol. 318 (7187). - P. 837-41.

36. Gleeson A. Major trauma - major problem / A. Gleeson // Journal of Irish Colleges of Physicians and Surgeons. 2000. - Vol. 29. - P. 69-71.

37. Healy J. Welfare Options: Delivering Social Services / J. Healy. - Sydney: Allen \& Unwin, 1998.

38. Hunt C. E. Trends in clinical education of medical students: implications for paediatrics / C. E. Hunt, G. A. Kallenberg, M. E. Whitcomb // Archives of Paediatric and Adolescent Medicine. - 1999. - Vol. 153. - P. 297-302.

39. James A. M. Closing rural hospitals in Saskatchewan: on the road to wellness? / A. M. James // Social Science and Medicine. - 1999. - Vol. 49(8). - P. 1021-34.

40. Kulzhanov M. Health Care Systems in Transition: Kazakhstan / M. Kulzhanov, J. Healy. - Copenhagen : European Observatory on Health Care Systems, 1999.

41. McKee M. Hours of work of junior hospital doctors: is there a solution? / M. McKee, N. Black // Journal of Management Medicine. - 1991. - Vol. 5. - P. 40-54.

42. McKee M. Meeting local needs / M. McKee, A. Clarke, B. Tennison // British Medical Journal. - 1993. - Vol. 306. P. 602.

43. McKee M. The impact of managed care on clinical research / M. McKee, E. Mossialos // Pharmacoeconomics. 1998. - Vol. 14. - P. 19-25.

44. Nicholl J. Effectiveness of a regional trauma system in reducing mortality from major trauma before and after study / J. Nicholl, J. Turner // British Medical Journal. - 1997. - Vol. 315. - P. 1349-54.

45. Non-urgent care in the hospital medical emergency department in France: how much and which health needs does it reflect? / Lang T., Davido A., Diakite B. [et al.] // Journal of Epidemiology and Community Health. - 1996. - Vol. 50. - P. 456-62.

46. Outcome of hospitalized injured patients after institution of a trauma system in an urban area / Mullins R. J., VeumStone J., Helfand M. [et al.] // Journal of the American Medical Association. - 1994. - Vol. 271. - P. $1919-24$.

47. Porter R. The Greatest Benefit to Mankind: A Medical History of Humanity from Antiquity to the Present / R. Porter. London: HarperCollins, 1997.

48. Rivett G. The Development of the London Hospital System 1823-1982 / G.Rivett. - London : King's Fund, 1986.

49. Round A. Emergency medical admissions to hospital - the influence of supply factors / A. Round // Public Health. 1997. - Vol. 111(4). - P. 221-4.

50. Rural hospitals and the local economy: a needed extension and refinement of existing empirical research / Cordes S., van der Sluice E., Lamphear C., Hoffman J. // Journal of Rural Health. - 1999. - Vol. 15 (2). - P. 189-201.

51. Steedman D. J. Medical teams for accidents and major disasters / D. J. Steedman // Injury. - 1990. - Vol. 21. P. 206-8.

52. The costs and benefits of paramedic skills in pre-hospital trauma care / Nicholl J., Hughes S., Dixon S. [et al.] // Health Technology Assessment. - 1998. - Vol. 2. - P. 1-67.

53. Threats to applicability of randomised trials: exclusions and selective participation / Britton A., McKee M., Black N. [et al.] // Journal of Health Services Research and Policy. - 1999. - Vol. 4. - P. 112-21.

54. Tomlinson B. Report of the Inquiry into London's Health Service, Medical Education and Research / B. Tomlinson. London: HMSO, 1992.

55. Trunkey D. D. Trauma / D. D. Trunkey // Scientific American. - 1983. - Vol. 249. - P. 28-35.

56. University of York (1998) Project Preparation for the Kazakhstan Health Sector Project: Final Report. Almaty: Ministry of Education, Culture and Health and Fund for Compulsory Health Insurance.

57. WHO. European Health for All Database. -Copenhagen : WHO Regional Office for Europe, 2001.

58. Zimbabwe's hospital referral system: does it work? / Sanders D., Kravitz J., Lewin S., McKee M. // Health Policy and Planning. - 1998. - Vol. 13. - P. 359-70. 
РОЛЬ И ФУНКЦИЯ БОЛЬНИЦ (АНАЛИТИЧЕСКИЙ ОБЗОР ЛИТЕРАТУРЫ)

Г.Я. Пархоменко ${ }^{1}$ В.Г. Слабкий

'ГУ “Украинский институт стратегических исследований МЗ Украины", г. Киев

²Ужгородский национальный университет, Украина

Цель: проанализировать источники научной литературы относительно роли и функций больниц.

Материалы и методы. В исследовании применялся библиосемантический метод - проанализированы 58 источников научной литературы.

Результаты. Центральной функцией больниц является лечение больных, однако роль больницы нельзя ограничивать только этой функцией, больница также может быть важным местом для обучения и проведения научных исследований, поддерживать близлежащие учреждения здравоохранения. Больница, предоставляющая много рабочих мест, играет важную социальную роль.

Выводы. Ожидания, связанные с каждой из функций, значительно влияют на организацию деятельности больницы и на структуру ее связей. Полученные в ходе исследования результаты должны быть использованы при разработке стратегии дальнейшего проведения реформы системы здравоохранения в Украине и формирования сети больниц на всех уровнях управления.

КЛЮЧЕВЫЕ СЛОВА: больница, роль, функции, мировой опыт.

\section{ROLE AND FUNCTION OF HOSPITALS (ANALYTICAL REVIEW OF LITERATURE)}

G.Ya. Parkhomenko', V.G. Slabkyi

${ }^{1} \mathrm{PE}$ "Ukrainian Institute of Strategic Researches MHC of Ukraine", Kyiv

'Uzhhorod National University, Ukraine

Purpose: to analyze sources of scientific literature on the role and functions of hospitals.

Materials and methods. In study it is applied bibilosemantyck method - 58 scientific literature sources are analyzed.

Results. The central function of hospitals is treatment of patients, but the hospital role not is limited only to this function, the hospital also can be an important site for education and carrying out of scientific researches, support nearby health facilities. The hospital giving many workplaces, plays an important social role.

Conclusions. Expectations connected with each of functions significantly influence the organization of hospital activity and on structure of its communications. The results received during study should be used in the development of strategy of further reform of the health care system in Ukraine and formation of a network of hospitals at all levels of management.

KEY WORDS: hospital, role, functions, world experience.

Рукопис надійшов до редакції 09.10.2014 р.

\section{Відомості про авторів:}

Пархоменко Георгій Якович - к.мед.н., лікар вищої категорії, головний лікар центру «Новий зір», пошукач ду "Український інститут стратегічних досліджень МОЗ України"; тел. +38 (044) 576-41-19. Слабкий Василь Геннадійович - ДУ "Український інститут стратегічних досліджень МОЗ України"; тел. +38 (044) 576-41-19. 